\title{
IDENTIFIKASI SIKLAMAT PADA KUAH DADAR GULUNG YANG DIJUAL DI KAWASAN PELABUHAN RAMBANG KOTA PALANGKA RAYA
}

\author{
${ }^{1}$ Nurul Qamariah, ${ }^{2}$ Karmila \\ ${ }^{1}$ Dosen Program Studi D-III Farmasi Fakultas IImu Kesehatan \\ Universitas Muhammadiyah Palangkaraya \\ ${ }^{2}$ Mahasiswa Program Studi D-III Farmasi Fakultas IImu Kesehatan \\ Universitas Muhammadiyah Palangkaraya
}

\begin{abstract}
ABSTRAK
Dalam Peraturan Menteri Kesehatan Republik Indonesia Nomor 033 Tahun 2012 tentang Bahan Tambahan Pangan (BTP) menyebutkan BTP yang digunakan dalam pangan salah satunya adalah pemanis (Sweetener). Pemanis adalah bahan tambahan yang dapat menyebabkan rasa manis pada pangan, tetapi tidak memiliki nilai gizi, salah satunya adalah Siklamat. Siklamat memiliki tingkat kemanisan \pm 30 kali kemanisan sukrosa (tanpa rasa pahit). Berdasarkan Peraturan Kepala Badan Pengawas Obat dan Makanan Republik Indonesia Nomor 4 Tahun 2014 tentang Batas Maksimum Penggunaan Bahan Tambahan Pangan Pemanis, mengenai kategori pangan sampel kuah dadar gulung termasuk ke dalam kategori pangan yaitu sirup untuk hiasan produk bakeri dan es, dengan memiliki batas maksimum sebesar $500 \mathrm{mg} / \mathrm{kg}$.

Tujuan dari penelitian ini adalah untuk mengetahui apakah kuah dadar gulung yang dijual di Kawasan Pelabuhan Rambang Kota Palangka Raya mengandung pemanis buatan siklamat. Penelitian ini termasuk jenis penelitian eksperimen dengan melakukan serangkaian percobaan yang kemudian data yang diperoleh dari hasil penelitian laboratorium tersebut diolah dan dibahas secara deskriptif. Sampel penelitian adalah kuah dadar gulung yang dijual di Kawasan Pelabuhan Rambang Kota Palangka Raya. Teknik pengumpulan data dengan menggunakan sampling jenuh yaitu dengan mengambil semua populasi sebagai sampel karena jumlah populasi relatif kecil, kemudian data dibuat dalam bentuk tabel. Pengambilan sampel dilakukan pada tanggal 19 Mei 2016 Pukul 14.50 WIB untuk sampel pertama, pukul 15.00 WIB untuk sampel kedua dan pukul 15.15 WIB untuk sampel yang ketiga.

Dari hasil identifikasi pemanis buatan siklamat pada kuah dadar gulung yaitu pada sampel 1, sampel 2 dan sampel 3, setelah diuji tidak terdapat endapan putih seperti yang terjadi pada kontrol positif. Sehingga dapat disimpulkan bahwa sampel tersebut tidak terdeteksi mengandung siklamat.
\end{abstract}

Kata Kunci: Siklamat, Kuah Dadar Gulung, Uji Pengendapan. 


\section{PENDAHULUAN}

BerdasarkanUndang-Undang Republik Indonesia Nomor 36 tahun 2009 tentang Kesehatan menyebutkan bahwa Kesehatan adalah keadaan sehat, baik secara fisik, mental, spiritual maupun sosial yang memungkinkan setiap orang untuk hidup produktif secara sosial dan ekonomis. Kesehatan juga sangat berhubungan erat dengan pangan. Pangan sangat mempengaruhi kesehatan seseorang. Manusia membutuhkan pangan sebagai sumber tenaga untuk melakukan kegiatan sehari-hari. Oleh karena itu, pangan yang dikonsumsi haruslah bergizi, aman, sehat, dan tidak menimbulkan gangguan kesehatan.

Produk pangan sekarang ini beragam bentuknya, baik dari segi jenis maupun dari segi rasa dan cara pengolahannya, dengan semakin pesatnya teknik pengolahan pangan, penambahan bahanbahan aditif pada produk pangan sulit untuk dihindari, satu diantara bahan aditif tersebut adalah pemanis buatan. Pemanis merupakan senyawa kimia yang sering ditambahkan dan digunakan untuk keperluan produk olahan pangan.

Pemanis berfungsi untuk meningkatkan cita rasa dan aroma, memperbaiki sifat fisik, sebagai pengawet, memperbaiki sifat-sifat kimia sekaligus merupakan sumber kalori bagi tubuh. Pemanis buatan adalah bahan tambahan makanan untuk menggantikan rasa manis gula yang biasanya mengandung sedikit energi (Eriawan dan Imam, 2002).

Dilihat dari sumber pemanis dapat dikelompokkan menjadi pemanis alami dan pemanis buatan (sintetis). Pemanis alami biasanya berasal dari tanaman. Tanaman penghasil pemanis yang utama adalah tebu dan bit. Bahan pemanis yang dihasilkan dari kedua tanaman tersebut dikenal sebagai gula alam atau sukrosa. Sedangkan pemanis buatan adalah bahan tambahan pangan yang dapat menyebabkan rasa manis pada pangan, tetapi tidak memiliki nilai gizi. Beberapa pemanis yang telah dikenal dan banyak digunakan adalah sakarin, siklamat dan aspartam (Cahyadi, 2012).

Siklamat merupakan pemanis buatan yang tidak menghasilkan energi. Siklamat biasa terdapat sebagai garam natrium atau kalsium yang kemanisannya kurang lebih 30 kali lebih manis daripada sukrosa, sehingga biasanya terdapat dalam makanan atau minuman dengan kadar relatif kecil (Rohman dan Sumantri, 2007).

Efek negatif dari penggunaan siklamat tersebut antara lain, dapat merangsang pertumbuhan kanker kandung kemih, alergi, binggung, diare, hipertensi, impotensi, iritasi, insomnia, kehilangan daya ingat, migrain dan sakit kepala. Selain itu efek negatif pemanis buatan bagi anak-anak adalah merangsang keterbelakangan mental, hal ini terjadi karena otak masih dalam tahap perkembangan dan proses terakumulasi 
pemanis buatan pada jaringan syaraf (Winarno, 1994)

Pelabuhan adalah suatu tempat di perairan (di muara sungai, teluk atau pantai) dimana dijadikan sebagai sarana dan prasarana diselenggarakannya untuk kepentingan masyarakat umum. Salah satu pelabuhan yang ada di Kota Palangka Raya yaitu Pelabuhan Rambang. Dimana Pelabuhan Rambang terletak di Jalan Rindang Banua Kecamatan Pahandut Kota Palangka Raya, Kalimantan Tengah.

Sejalan dengan kemajuan zaman Pelabuhan Rambang selain menjadi pelabuhan bongkar muat barang, Pelabuhan Rambang Palangka Raya juga menjadi tempat bersantai bagi masyarakat yang ada di daerah tersebut.

Salah satu keunikan dari Pelabuhan Rambang ini adalah banyaknya para pedagang yang menggelar dagangannya di daerah Pelabuhan Rambang tersebut dengan suasana yang nyaman untuk bersantai, sehingga banyak para pengunjung yang datang. Selain untuk mencicipi makanan dan minuman juga menikmati suasana sejuk hembusan angin sungai Kahayan di Pelabuhan Rambang.

Salah satu dagangan atau jajanan yang ada di Pelabuhan Rambang Kota Palangka Raya yaitu kuah dadar gulung. Dimana kuah dadar gulung merupakan jajanan yang memiliki rasa manis, sehingga banyak pengunjung yang menyukai jajanan tersebut. Dadar gulung merupakan makanan khas Indonesia yang ada dibeberapa tempat dan dijadikan sebagai jajanan wajib pada setiap acara. Dadar gulung termasuk kedalam kue basah, dimana pembuatan dadar gulung yang diberi siraman kuah santan tidak jauh berbeda dengan dadar gulung yang pada umumnya diberi isi parutan kelapa. Dadar gulung yang diberi siraman kuah santan dapat memberikan rasa manis saat dikonsumsi bersamaan dengan dadar gulung.

Menurut Peraturan Kepala Badan Pengawas Obat dan Makanan Republik Indonesia Nomor 4 Tahun 2014 tentang Batas Maksimum Penggunaan Bahan Tambahan Pangan Pemanis, mengenai kategori pangan dari semua kategori yang ada, sampel kuah dadar gulung termasuk ke dalam kategori pangan yaitu sirup untuk hiasan produk bakeri dan es, dengan memiliki batas maksimum sebesar $500 \mathrm{mg} / \mathrm{kg}$. Adanya peraturan bahwa penggunaan siklamat masih diperbolehkan, serta kemudahan mendapatkannya dengan harga relatif murah dibandingkan dengan gula alam, menyebabkan produsen pangan dan minuman terdorong untuk menggunakan pemanis buatan tersebut di dalam makanan atau minuman.

Ditinjau dari uraian diatas, di Kota Palangka Raya belum pernah dilakukan penelitian terhadap kandungan pemanis buatan siklamat pada kuah dadar gulung yang dijual pedagang di Kawasan 
Pelabuhan Rambang Kota Palangka

Raya. Hal ini dikarenakan sulitnya untuk mengetahui apakah makanan atau minuman yang dikonsumsi mengandung siklamat atau tidak secara langsung, karena rasa siklamat yang tidak memiliki rasa sampingan seperti rasa pahit dan getir di lidah sehingga harus dilakukan identifikasi lebih lanjut di laboratorium.

\section{METODE PENELITIAN}

\section{Jenis dan Rancangan Penelitian}

Jenis penelitian yang dilakukan adalah metode eksperimen atau percobaan (experiment research) dengan pendekatan laboratorium yang dilakukan melalui serangkaian percobaan. Metode penelitian eksperimen atau percobaan (experiment research) adalah kegiatan percobaan (eksperiment) yang bertujuan untuk mengetahui suatu gejala atau pengaruh yang timbul, sebagai akibat dari adanya perlakuan tertentu. Ciri khusus dari penelitian eksperimen adalah adanya percobaan atau trial (Notoatmodjo, 2010).

Dalam penelitian ini, peneliti menggambarkan ada atau tidaknya kandungan siklamat dalam kuah dadar gulung yang dijual di Kawasan Pelabuhan Rambang Kota Palangka Raya.

\section{Waktu dan Tempat Penelitian}

Penelitian dilaksanakan selama 5 bulan dari bulan Februari - Juni 2016, dimulai dari observasi, pengambilan sampel, analisis dan mendapatkan hasil. Tempat percobaan/uji laboratorium ini dilakukan di Laboratorium Kimia Fakultas IImu Kesehatan Universitas Muhammadiyah Palangkaraya.

\section{Populasi dan Sampel}

\section{Populasi}

Populasi adalah keseluruhan objek penelitian atau objek yang diteliti (Notoatmodjo, 2010). Populasi yang digunakan dalam penelitian ini adalah kuah dadar gulung yang dijual oleh 3 (tiga) pedagang di Kawasan Pelabuhan Rambang Kota Palangka Raya.

2. Sampel

Sampel adalah sebagian yang diambil dari keseluruhan objek yang diteliti dan dianggap mewakili seluruh populasi (Notoatmodjo, 2010).

Sampel atau objek yang digunakan pada penelitian ini adalah 3 (tiga) sampel kuah dadar gulung yang dijual oleh pedagang di Kawasan Pelabuhan Rambang Kota Palangka Raya.

\section{Teknik Pengambilan Sampel}

Teknik pengambilan sampel yang digunakan dalam penelitian ini yaitu pengambilan sampel secara sampling jenuh. Sampling Jenuh adalah teknik penentuan sampel bila semua anggota populasi digunakan sebagai sampel. Hal ini sering dilakukan bila jumlah populasi 
relatif kecil, kurang dari 30 orang, atau penelitian yang ingin membuat generalisasi dengan kesalahan yang sangat kecil. Istilah lain sampel jenuh adalah sensus, dimana semua anggota populasi dijadikan sampel (Sugiyono, 2010).

Dimana berdasarkan hasil survei yang dilakukan pada saat pengambilan sampel yaitu pada hari kamis tanggal 19 Mei 2016 pukul 14.50 WIB dilakukan pengambilan sampel untuk sampel yang pertama, lalu untuk sampel yang kedua dilakukan pengambilan sampel pada pukul 15.00 WIB dan untuk sampel yang ketiga pengambilan sampel dilakukan pada pukul 15.15 WIB. Sampel yang diambil dari masing-masing pedagang tersebut diambil terpisah dimana dadar gulung dipisahkan dari kuahnya yang digunakan. Sampel yang diambil berasal dari kawasan yang sama yaitu Kawasan Pelabuhan Rambang yang terletak di jalan Rindang Banua Kecamatan Pahandut Kota Palangka Raya, Kalimantan Tengah.

\section{Instrumen Penelitian}

1. Alat

Alat-alat yang digunakan dalam penelitian ini yaitu neraca digital, gelas ukur $100 \mathrm{~mL}$, pipet tetes, kertas saring Whatmann 42, batang pengaduk, sendok tanduk, erlenmeyer $250 \mathrm{~mL}$, tissue, beaker glass $100 \mathrm{~mL}$, beaker glass $250 \mathrm{~mL}$, corong, pipet volume 25
$\mathrm{mL}$, pipet ukur $10 \mathrm{~mL}$, hot plate, alumunium foil, botol semprot, dan labu ukur $250 \mathrm{~mL}$.

\section{Bahan}

Adapun bahan-bahan yang digunakan dalam penelitian $\mathrm{KTI}$ ini adalah sampel (kuah dadar gulung), karbon aktif (norit), aquadest, kemudian pereaksi $\mathrm{HCl} 10 \%$, NaNO2 10\%, BaCl2 10\%, dan baku Natrium Siklamat.

\section{Prosedur Kerja}

1. Pengambilan dan Penyiapan Sampel

Sampel diambil dari tiga pedagang di Kawasan Pelabuhan Rambang Kota Palangka Raya kemudian diuji di Laboratorium Kimia Universitas Muhammadiyah Palangka Raya.

\section{Kontrol Positif}

a. Mengambil $100 \mathrm{~mL}$ sampel kuah dadar gulung yang mengandung baku siklamat $1 \%$.

b. Tambahkan arang aktif (norit) hingga larut, kemudian saring menggunakan kertas saring hatmann 42 (apabila perlakuan ditambahkan arang aktif).

c. Tambahkan dengan $10 \mathrm{~mL}$ larutan $\mathrm{HCl} 10 \%$ dan tambahkan dengan $10 \mathrm{~mL}$ larutan $\mathrm{BaCl} 210 \%$, biarkan selama 30 menit.

a. Saring dengan menggunakan kertas Whatmann 42, kemudian tambahkan $10 \mathrm{~mL}$ larutan $\mathrm{NaNO} 2$ $10 \%$. 
b. Setelah itu panaskan di atas hot plate.

c. Hasil yang diperoleh didiamkan sekitar 20-30 menit setelah dipanaskan, jika terdapat endapan berwarna putih berarti positif terdeteksi mengandung siklamat.

3. Kontrol Negatif

a. Mengambil $100 \mathrm{~mL}$ sampel kuah dadar gulung yang tidak mengandung pemanis siklamat.

b. Tambahkan arang aktif (norit) hingga larut, kemudian saring menggunakan kertas saring Whatmann 42 (apabila perlakuan ditambahkan arang aktif).

d. Tambahkan dengan $10 \mathrm{~mL}$ larutan $\mathrm{HCl} 10 \%$ dan tambahkan dengan $10 \mathrm{~mL}$ larutan $\mathrm{BaCl} 210 \%$, biarkan selama 30 menit.

e. Saring dengan menggunakan kertas Whatmann 42, kemudian tambahkan $10 \mathrm{~mL}$ larutan $\mathrm{NaNO} 2$ $10 \%$.

f. Setelah itu panaskan di atas hot plate.

g. Hasil yang diperoleh didiamkan sekitar 20-30 menit setelah dipanaskan, jika tidak terdapat endapan berwarna putih berarti tidak terdeteksi mengandung siklamat.

4. Uji Pengendapan

a. Mengambil sebanyak $100 \mathrm{~mL}$ sampel. b. Tambahkan arang aktif (norit) hingga larut, kemudian saring menggunakan kertas saring Whatmann 42 (apabila perlakuan ditambahkan arang aktif).

b. Tambahkan dengan $10 \mathrm{~mL}$ larutan $\mathrm{HCl} 10 \%$ dan tambahkan dengan $10 \mathrm{~mL}$ larutan $\mathrm{BaCl} 2$ 10\%, biarkan selama 30 menit.

c. Saring dengan menggunakan kertas Whatmann 42, kemudian tambahkan $10 \mathrm{~mL}$ larutan $\mathrm{NaNO} 2$ $10 \%$.

d. Setelah itu panaskan di atas hot plate.

e. Hasil yang diperoleh didiamkan sekitar 20-30 menit setelah dipanaskan, jika terdapat endapan berwarna putih berarti sampel positif terdeteksi mengandung siklamat (SNI 01-2893-1992).

\section{Penetapan Kadar dengan Metode}

\section{Gravimetri}

a. Mengambil sebanyak $100 \mathrm{~mL}$ sampel.

b. Tambahkan arang aktif (norit) hingga larut, kemudian saring menggunakan kertas saring Whatmann 42 (apabila perlakuan ditambahkan arang aktif).

b. Tambahkan dengan $10 \mathrm{~mL}$ larutan $\mathrm{HCl} 10 \%$ dan tambahkan dengan $10 \mathrm{~mL}$ larutan $\mathrm{BaCl} 210 \%$, biarkan selama 30 menit. 
c. Saring dengan menggunakan kertas Whatmann 42, kemudia tambahkan $10 \mathrm{~mL}$ larutan $\mathrm{NaNO} 2$ $10 \%$.

d. Setelah itu panaskan di atas hot plate.

e. Endapan yang terjadi, disaring, dicuci, dikeringkan, dan ditimbang (SNI 01-6684-2002).

f.

\section{g. Analisis Data}

h. Data yang diperoleh dari hasil penelitian diolah secara manual dan analisa secara deskriptif. Analisa deskriptif merupakan penganalisa data untuk memperoleh tema dan pola-pola yang dideskripsikan dan diilustrasikan dengan contohcontoh, termasuk kutipan-kutipan dan rangkaian dari dokumen, koding data, dan analisa verbal (Lestari, 2011).

i. Analisis deskriptif ini digunakan untuk mendeskripsikan hasil penelitian dari uji laboratorium. Data-data yang diperoleh disajikan dalam bentuk tabel, kemudian dibahas dengan membandingkan hasil terhadap kontrol positif $(+)$ dan kontrol negatif (-).

j. Berdasarkan

(Rahmansyah, 2015). Untuk analisis kuantitatif, data yang didapat dianalisis dengan menggunakan rumus : k. Kadar siklamat sebagai garam Nasiklamat :

I.

$$
\overline{\mathrm{B} 2} X 0,8621=\cdots g / L
$$

Kadar siklamat sebagai As-siklama $\frac{\text { Bm. As }- \text { siklamat }}{\text { Bm. Na - siklamat }} X \ldots g / L=\cdots g / l$ m. Keterangan :

n. B1 : Bobot endapan BaSO4 dalam gram

o. B2 : Bobot contoh dalam liter

p. Bm : Berat Molekul

q.

r. HASIL DAN PEMBAHASAN

s. Hasil

t. Penelitian dilakukan di Laboratorium Kimia Universitas Muhammadiyah Palangka Raya yaitu identifikasi siklamat pada campuran santan dan sirup merah yang terdapat pada kuah dadar gulung yang dijual di Kawasan Pelabuhan Rambang Kota Palangka Raya. Penelitian ini bertujuan untuk menentukan apakah kuah dadar gulung tersebut mengandung pemanis buatan siklamat atau tidak.

u. Identifikasi pemanis buatan siklamat tersebut dilakukan dengan uji pengendapan. Sampel campuran santan dan sirup merah yang terdapat pada kuah dadar gulung diambil dari 3 (tiga) sampel yang dijual di Kawasan Pelabuhan Rambang Kota Palangka Raya. 
V.

Tabel 2. Hasil Uji Organoleptik Pada Kuah Dadar Gulung yang Dijual Di

Kawasan Pelabuhan Rambang Kota Palangka Raya

\begin{tabular}{|c|c|c|c|c|c}
\hline \multirow{2}{*}{ No } & \multirow{2}{*}{ Sampel } & \multicolumn{4}{|c}{ Uji Organoleptik } \\
\cline { 3 - 6 } & Warna & Rasa & Bau & Bentuk \\
\hline 1 & Sampel 1 & Merah Muda & Manis & Khas Sirup & Cair \\
\hline 2 & Sampel 2 & Merah Muda & Manis & Khas Sirup & Cair \\
\hline 3 & Sampel 3 & Merah Muda & Manis & Khas Sirup & Cair \\
\hline
\end{tabular}


w.

\begin{tabular}{c|c|c|c|c|}
\multicolumn{5}{c}{ Kawasan Pelabuhan Rambang Kota Palangka Raya } \\
\hline No & Sampel & $\begin{array}{c}\text { Baku Pembanding } \\
\text { (SNI 01-2893- } \\
\text { 1992) }\end{array}$ & Hasil & Keterangan \\
\hline 1 & Kontrol Positif (+) & Endapan Putih & Terdapat & Positif \\
& Tidak Menggunakan \\
Karbon Aktif & & Endapan Putih & $(+)$
\end{tabular}

$\mathbf{x}$.

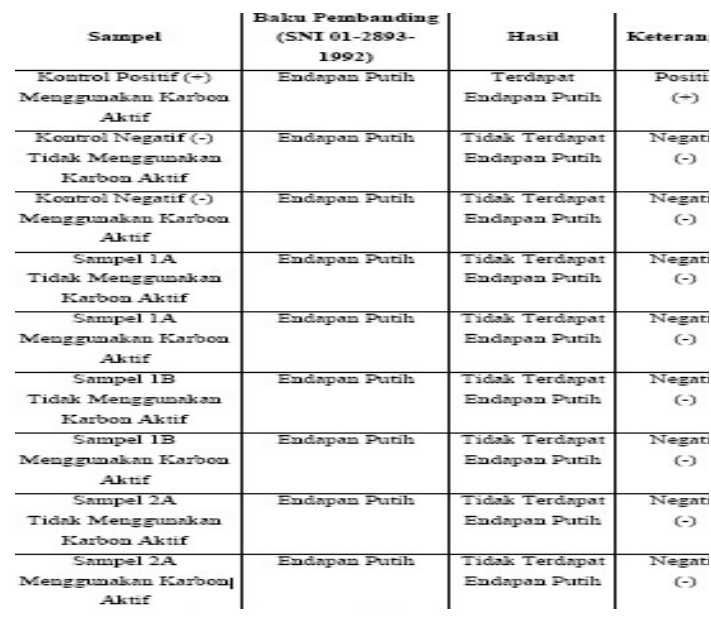

y. z.

\begin{tabular}{|c|c|c|c|c|}
\hline 0 & Sampel & $\begin{array}{c}\text { Baku Pembanding } \\
\text { (SNI 01-2893- } \\
\text { 1992) }\end{array}$ & Hasil & Keterangan \\
\hline I & $\begin{array}{c}\text { Sampel 2B } \\
\text { Tidak Menggunakan } \\
\text { Karbon Aktif }\end{array}$ & Endapan Putih & $\begin{array}{l}\text { Tidak Terdapat } \\
\text { Endapan Putih }\end{array}$ & $\begin{array}{l}\text { Negatif } \\
(-)\end{array}$ \\
\hline E & $\begin{array}{c}\text { Sampel 2B } \\
\text { Menggunakan Karbon } \\
\text { Aktif }\end{array}$ & Endapan Putih & $\begin{array}{l}\text { Tidak Terdapat } \\
\text { Endapan Putih }\end{array}$ & $\begin{array}{l}\text { Negatif } \\
(-)\end{array}$ \\
\hline 5 & $\begin{array}{c}\text { Sampel 3A } \\
\text { Tidak Menggunakan } \\
\text { Karbon Aktif }\end{array}$ & Endapan Putih & $\begin{array}{l}\text { Tidak Terdapat } \\
\text { Endapan Putih }\end{array}$ & $\begin{array}{c}\text { Negatif } \\
(\rightarrow)\end{array}$ \\
\hline$F$ & $\begin{array}{c}\text { Sampel 3A } \\
\text { Menggunakan Karbon } \\
\text { Aktif }\end{array}$ & Endapan Putih & $\begin{array}{l}\text { Tidak Terdapat } \\
\text { Endapan Putih }\end{array}$ & $\begin{array}{c}\text { Negatif } \\
(\rightarrow)\end{array}$ \\
\hline 5 & $\begin{array}{c}\text { Sampel 3B } \\
\text { Tidak Menggunakan } \\
\text { Karbon Alktif }\end{array}$ & Endapan Putih & $\begin{array}{l}\text { Tidak Terdapat } \\
\text { Endapan Putih }\end{array}$ & $\begin{array}{c}\text { Negatif } \\
(-)\end{array}$ \\
\hline 5 & $\begin{array}{c}\text { Sampel 3B } \\
\text { Menggunakan Karbon } \\
\text { Aktif }\end{array}$ & Endapan Putih & $\begin{array}{l}\text { Tidak Terdapat } \\
\text { Endapan Putih }\end{array}$ & $\begin{array}{c}\text { Negatif } \\
(-)\end{array}$ \\
\hline
\end{tabular}

aa. Pembahasan

ab. Prinsip identifikasi adanya siklamat dalam sampel yaitu dengan cara pengendapan. Pengendapan dilakukan dengan cara menambahkan barium klorida dalam suasana asam kemudian ditambahkan natrium nitrit sehingga akan terbentuk endapan.

ac. Sampel pada penelitian ini adalah kuah dadar gulung yang diambil dari tiga pedagang yang berjualan di Kawasan Pelabuhan Rambang Kota Palangka Raya. Pada preparasi sampel dilakukan dengan dua perlakuan yaitu sampel tidak ditambahkan karbon aktif (norit) dan sampel dilakukan penambahan karbon aktif (norit). Dimana penambahan karbon aktif atau norit berfungsi untuk menjernihkan sampel sehingga ketika 
identifikasi berlangsung bisa lebih mudah mengamati reaksi-reaksi yang terjadi pada sampel, sehingga dilakukan dua perlakuan tersebut untuk membandingkan hasil yang diperoleh.

ad. Penambahan $\mathrm{HCl} 10 \%$ dalam sampel berfungsi untuk mengasamkan larutan. Larutan dibuat dalam keadaan asam agar reaksi yang akan terjadi dapat lebih mudah bereaksi. Penambahan $\mathrm{BaCl} 210 \%$ dalam sampel berfungsi untuk mengendapkan pengotor-pengotor yang ada dalam larutan, seperti adanya ion karbonat. Penambahan NaNO2 10\% dalam sampel berfungsi untuk memutuskan ikatan sulfat dalam siklamat. Ketika ikatan sulfat telah diputus maka ion $\mathrm{Ba} 2+$ akan bereaksi dengan ion sulfat dan menghasilkan endapan barium sulfat (BaSO4).

ae. Gambar 3. Reaksi Pembentukan Endapan Barium Sulfat

af.

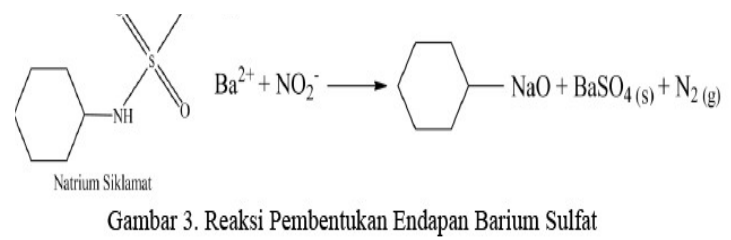

Sumber: (Rianti, 2016). 
ag. Uji pengendapan adalah suatu uji pendahuluan yang dilakukan untuk mengetahui adanya kandungan siklamat pada suatu sampel dengan ditandai terbentuknya suatu reaksi endapan dari suatu sampel yang diuji, untuk identifikasi dengan uji pengendapan, dibuat kontrol positif dan negatif sebagai pembanding yang digunakan untuk mengetahui reaksi kimia pada sampel jika terdeteksi mengandung siklamat atau tidak terdeteksi mengandung siklamat.

ah. Dalam pembuatan kontrol positif siklamat digunakan sampel kuah dadar gulung yang mengandung baku siklamat $1 \%$ selanjutnya ditambahkan arang aktif (norit) hingga larut, kemudian saring menggunakan kertas saring Whatmann 42 (apabila perlakuan ditambahkan arang aktif). Kemudian tambahkan $10 \mathrm{~mL}$ larutan $\mathrm{HCl} 10 \%$ dan $10 \mathrm{~mL}$ larutan $\mathrm{BaCl} 210 \%$ warna menjadi keruh dan dibiarkan selama 30 menit. Kemudian disaring menggunakan kertas saring Whatmann 42, kemudian menambahkan $10 \mathrm{~mL}$ larutan NaNO2 10\% kedalam hasil saringan, warna menjadi keruh dan sedikit berbuih. Kemudian dipanaskan di atas penangas air (hot plate) dan didiamkan selama 20-30 menit. Setelah didiamkan hasil yang didapat yaitu terdapat endapan berwarna putih. Kontrol positif digunakan untuk mengetahui reaksi kimia pada sampel jika terdeteksi mengandung siklamat. ai. Pada kontrol negatif dilakukan perlakuan yang sama dengan sampel kuah dadar gulung yang tidak mengandung baku siklamat $1 \%$ selanjutnya ditambahkan arang aktif (norit) hingga larut, kemudian saring menggunakan kertas saring Whatmann 42 (apabila perlakuan ditambahkan arang aktif). Kemudian tambahkan $10 \mathrm{~mL}$ larutan $\mathrm{HCl} 10 \%$ dan $10 \mathrm{~mL}$ larutan $\mathrm{BaCl} 2$ 10\% warna menjadi keruh dan dibiarkan selama 30 menit. Kemudian disaring menggunakan kertas saring Whatmann 42, kemudian menambahkan $10 \mathrm{~mL}$ larutan NaNO2 10\% kedalam hasil saringan, warna menjadi keruh dan sedikit berbuih. Kemudian dipanaskan di atas penangan air (hot plate) dan didiamkan selama 20-30 menit. Setelah didiamkan hasil yang didapat yaitu tidak terdapat endapan berwarna putih. Kontrol negatif digunakan untuk mengetahui reaksi kimia yang terjadi jika sampel tidak terdeteksi mengandung siklamat.

aj. Pengujian sampel 1, 2, dan 3 dilakukan dengan mengambil masingmasing sampel sebanyak $100 \mathrm{~mL}$ kemudian ditambahkan arang aktif (norit) hingga larut, kemudian saring menggunakan kertas saring Whatmann 42 (apabila perlakuan ditambahkan arang aktif). Selanjutnya ditambahkan $10 \mathrm{~mL}$ larutan $\mathrm{HCl} 10 \%$ dan $10 \mathrm{~mL}$ larutan $\mathrm{BaCl} 2$ $10 \%$ warna menjadi keruh dan dibiarkan selama 30 menit. Kemudian saring dengan menggunakan kertas saring 
ak. Whatmann 42, kemudian tambahkan $10 \mathrm{~mL}$ larutan NaNO2 $10 \%$ warna menjadi keruh dan sedikit berbuih. Kemudian dipanaskan di atas penangan air (hot plate) dan didiamkan selama 20-30 menit. Setelah didiamkan, hasil yang didapat yaitu tidak terdapat endapan berwarna putih pada semua sampel.

al. Masing-masing

pengujian dilakukan duplo (pengulangan sebanyak 2 kali) hal ini bertujuan untuk memastikan ada atau tidaknya kandungan siklamat di dalam sampel tersebut. Berdasarkan uji identifikasi pada kuah dadar gulung yang dijual di Kawasan Pelabuhan Rambang Kota Palangka Raya dengan menggunakan metode uji pengendapan diperoleh hasil yang menunjukkan semua sampel kuah dadar gulung tersebut tidak terdeteksi mengandung pemanis buatan jenis siklamat. Penambahan karbon aktif (norit) pada sampel tidak mempengaruhi hasil penelitian, karena natrium siklamat tidak ikut mengendap bersama-sama dengan karbon aktif (norit) pada saat preparasi sampel (Pembuktian bahwa dengan penambahan norit, maka tidak mempengaruhi kandungan siklamat).

am. Penetapan kadar siklamat dengan menggunakan metode gravimetri tidak dilakukan karena diketahui bahwa hasil uji pengendapan menunjukkan semua sampel pada kuah dadar gulung tersebut tidak terdeteksi mengandung pemanis buatan jenis siklamat. Bahan pemanis buatan siklamat atau yang lebih dikenal dengan nama "sari manis" umumnya ditambahkan di dalam makanan atau minuman dengan tujuan untuk menambah kelezatan rasa. Menurut Keputusan Kepala Badan Pengawas Obat dan Makanan Republik Indonesia (BPOM RI) Nomor 4 Tahun 2014 tentang Batas Maksimum Penggunaan Bahan Tambahan Pangan Pemanis, batas konsumsi harian siklamat yang aman (ADI) adalah 0- 11 $\mathrm{mg} / \mathrm{kg}$ berat badan. Berdasarkan Peraturan Kepala BPOM RI Nomor 4 Tahun 2014 pada tabel Batas Maksimum Penggunaan Bahan Tambahan Pangan Pemanis, mengenai kategori pangan dari semua kategori yang ada, sampel kuah dadar gulung termasuk ke dalam kategori yaitu sirup untuk hiasan produk bakeri dan es, dengan memiliki batas maksimum sebesar $500 \mathrm{mg} / \mathrm{kg}$. Hal ini tentu bertujuan untuk menghindari bahaya yang disebabkan dengan pengkonsumsian siklamat dalam kadar yang berlebih yang mampu memunculkan banyak gangguan bagi kesehatan, di antaranya tremor (penyakit syaraf), migrain dan sakit kepala, kehilangan daya ingat, bingung, insomnia, iritasi, asma, hipertensi, diare, sakit perut, alergi, impotensi dan gangguan seksual, kebotakan, dan kanker otak (Lestari, 2011). 
Identifikasi Siklamat Pada Kuah Dadar Gulung Yang Dijual Di Kawasan Pelabuhan Rambang Kota Palangka Raya

an. Melihat begitu banyaknya efek yang diakibatkan jika mengkonsumsi makanan 
ao. atau minuman yang mengandung siklamat, maka perlu dilakukan pengawasan terhadap setiap makanan atau minuman yang akan dikonsumsi.

ap.

\section{aq. KESIMPULAN}

ar. Berdasarkan hasil penelitian identifikasi siklamat pada kuah dadar gulung yang dijual di Kawasan Pelabuhan Rambang Kota Palangka Raya maka dapat disimpulkan bahwa 3 (tiga) sampel dengan menggunakan metode uji pengendapan, semua sampel tersebut tidak terdeteksi mengandung pemanis buatan jenis siklamat.

as.

\section{at. DAFTAR PUSTAKA}

au. Anggraeni, A. 2013. Identifikasi Pemanis Buatan Siklamat Pada Minuman Teh Yang Dijual Di Pelabuhan Rambang Palangka Raya. Palangka Raya: Fakultas IImu Kesehatan Universitas Muhammadiya Palangkaraya.

av. Badan POM. 2014. Peraturan Kepala Badan Pengawas Obat dan Makanan Republik Indonesia Nomor 04 tentang Batas Maksimum Penggunaan Bahan Tambahan Pangan Pemanis. Jakarta. aw. Badan Standarisasi Nasional (BSN). 1992. Cara Uji Pemanis Buatan. SNI 01- 2893-1992.

ax. Badan Standarisasi Nasional (BSN). 2002. Minuman Energi. SNI 01-66842002. ay. Cahyadi, W. Cetakan Ketiga. 2012. Analisis \& Aspek Kesehatan Bahan Tambahan Pangan. Edisi Kedua. Jakarta: Bumi Aksara.

az. Departemen Kesehatan Republik Indonesia. 2009. Undang-Undang Republik Indonesia Nomor 36 Tahun 2009 tentang Kesehatan. Jakarta.

ba. Ditjen POM. 1979. Farmakope Indonesia. Edisi III. Jakarta : Departemen Kesehatan RI. Hal. 407.

bb. Eriawan, R., dan Imam, P. 2002. Pangan dan Gizi untuk Kesehatan. Jakarta : Radja Grafindo Persada. Dalam Cahyadi, W. 2012. Analisis \& Aspek Kesehatan Bahan Tambahan Pangan. Edisi Kedua. Jakarta: Bumi Aksara.

bc. Eriawan, R., dan Imam, P. 2002. Pangan dan Gizi untuk Kesehatan. Jakarta : Radja Grafindo Persada. Dalam Sayuni, Muhammad. 2014. Analisa Siklamat dalam Sirup Pala dengan Metode Kualitatif. Online: http://muhammadsayuni.blogspot.co.i d/2014/06/analisa-siklamat dalamsirup-pala.html Diakses, 22 April 2016. Pukul 20:20 WIB.

bd. Gandjar, I.G., dan Rohman, A. 2012. Kimia Farmasi Analisis. Yogyakarta: Pustaka Pelajar. Dalam Amelia, Niky. 2015. Identifikasi Pemanis Buatan Siklamat Pada Minuman Kelapa Muda Yang Dijual Di Bawah Jembatan Kahayan Kota Palangka Raya. Palangka Raya: KTI Fakultas 
Nurul Qamariah dan Karmila

IImu Kesehatan Universitas

Muhammadiyah Palangkaraya.

Jurnal Surya Medika Volume 3 No. 1 [2017] 
be. Griya Kuliner. 2014. Dadar Gulung Siram Saus Santan. Online: http://griyakuliner.com/2014/01/23/dad ar-gulung-siram-saus-santan/html.

Diakses, 22 April 2016. Pukul 12:21 WIB.

bf. Lestari, D. 2011. Analisis Adanya Kandungan Pemanis Buatan (Sakarin dan Siklamat) Pada Jamu Gendong Di Pasar Gubug Grobogan. Semarang: Fakultas Tarbiyah Institut Agama Islam Negeri Walisongo. Dalam Rahmansyah, Bobby. 2015 Identifikasi Siklamat Pada Jamu Gendong Yang Dijual Di Pasar Besar Kota Palangka Raya. Palangka Raya: KTI Fakultas IImu Kesehatan Universitas Muhammadiyah Palangkaraya.

bg. Notoatmodjo, S. 2010. Metodelogi Penelitian Kesehatan. Jakarta : Rineka Cipta.

bh. Peraturan Menteri Kesehatan Republik Indonesia. 2012. Peraturan Menteri Kesehatan RI No. 033 Tahun 2012 tentang Bahan Tambahan Makanan. Jakarta.

bi. Rahmansyah, Bobby. 2015 Identifikasi Siklamat Pada Jamu Gendong Yang Dijual Di Pasar Besar Kota Palangka Raya. Palangka Raya: KTI Fakultas IImu Kesehatan Universitas Muhammadiyah Palangkaraya. bj. Rianti, Lia. 2016. Identifikasi Pemanis Buatan Siklamat Pada Minuman Es Teh Yang Dijual Di Kecamatan Sepang Kabupaaten Gunung Mas. Palangka Raya: KTI Fakultas IImu Kesehatan Universitas Muhammadiyah Palangkaraya.

bk. Rohman, A., dan Sumantri. 2007. Analisis Makanan. Yogyakarta: Gadjah Mada University Press.

bl. Shofia, Princess. 2016. Dadar Gulung Kuah Sirup Santan. Online: https;//cookpad.com/id/resep/752208dadar-gulung-kuah-sirupsantandadar- gulung/html. Diakses, 27 Mei 2016. Pukul 19:48 WIB.

bm. Sugiyono, Dr. 2010. Metodelogi Penelitian Kuantitatif Kualitatif dan $R \& D$, Penerbit, Alfabeta, Bandung.

bn. Winarno, F.G. 1994. Bahan Tambahan Untuk Makanan dan Kontaminan. Jakarta: Pustaka Sinar Harapan. Dalam Cahyadi, W. 2012. Analisis \& Aspek Kesehatan Bahan Tambahan Pangan. Edisi Kedua. Jakarta: Bumi Aksara.

bo. Winarno, F.G. 1997. Keamanan Pangan. Bogor : IPB. Dalam Cahyadi, W. 2012.

bp. Analisis \& Aspek Kesehatan Bahan Tambahan Pangan. Edisi Kedua. Jakarta: Bumi Aksara. 